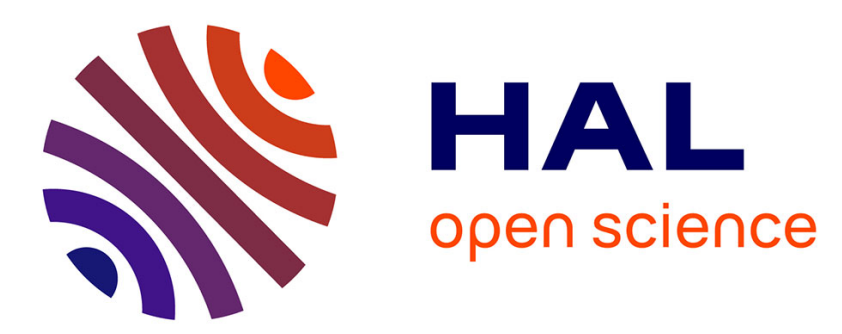

\title{
How will the COVID-19 pandemic affect the regions? A comparative analysis of the EU and ASEAN \\ Bruno Jetin
}

\section{To cite this version:}

Bruno Jetin. How will the COVID-19 pandemic affect the regions? A comparative analysis of the EU and ASEAN. 2021. halshs-03171573

\author{
HAL Id: halshs-03171573 \\ https://shs.hal.science/halshs-03171573 \\ Preprint submitted on 17 Mar 2021
}

HAL is a multi-disciplinary open access archive for the deposit and dissemination of scientific research documents, whether they are published or not. The documents may come from teaching and research institutions in France or abroad, or from public or private research centers.
L'archive ouverte pluridisciplinaire HAL, est destinée au dépôt et à la diffusion de documents scientifiques de niveau recherche, publiés ou non, émanant des établissements d'enseignement et de recherche français ou étrangers, des laboratoires publics ou privés. 


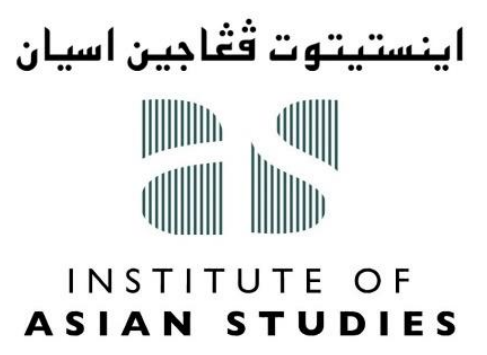

\title{
How will the COVID-19 pandemic affect the regions? A comparative analysis of the EU and ASEAN
}

\author{
Bruno Jetin
}

Universiti Brunei Darussalam

Working Paper No.63

Institute of Asian Studies, Universiti Brunei Darussalam

Gadong 2021 


\section{Editorial Board, Working Paper Series}

Professor Lian Kwen Fee, Institute of Asian Studies, Universiti Brunei Darussalam.

Associate Professor Paul J. Carnegie, Institute of Asian Studies, Universiti Brunei Darussalam.

\section{Authors}

Bruno Jetin is Associate Professor and Director of the Institute of Asian Studies, Universiti Brunei Darussalam. Prior to joining UBD, he was researcher at the Institute for Research on Contemporary Southeast Asia (IRASEC, CNRS-MAEE, Bangkok) and Associate Professor at the University Sorbonne Paris Nord where he was Deputy Director and then Acting Director (2010-2012) of the Research Center in Economics. He holds a PhD in economics from the University of Sorbonne Paris Nord. His current research areas include ASEAN and the Belt and Road Initiative, foreign investment and arbitration in Asia-Pacific, income distribution and growth. He is also an expert of the automobile industry and the electric car. He has published many articles, edited books, and chapter books for instance: L. Nottage, S. Ali, B. Jetin and N. Teramura, "New Frontiers in Asia-Pacific International Arbitration and dispute Resolution". (Kluwer Law International, Alphen aan den Rijn, The Netherlands, 2020); B. Jetin, "One Belt-One Road Initiative and ASEAN Connectivity: Synergy Issues and Potentialities". In B.R. Deepak (ed.): “China's Global Rebalancing and the New Silk Road". (Springer, Singapore, 2017); B. Jetin and M. Mikic (eds.), “ASEAN Economic community: a model for Asia-wide Integration?" (Palgrave McMillan, 2016); B. Jetin and Luis Reyes (2020). "Wage-led demand as a rebalancing strategy for economic growth in China". Journal of Post Keynesian Economics. 43(3): 341-366. B. Jetin (2020). "Who will control the electric vehicle market?" International Journal of Automobile Technology and Management, 20(2): 156-177.

Contact: bruno.jetin@ubd.edu.bn

The Views expressed in this paper are those of the author(s) and do not necessarily reflect those of the Institute of Asian Studies or the Universiti Brunei Darussalam.

(C) Copyright is held by the author(s) of each working paper; no part of this publication may be republished, reprinted or reproduced in any form without permission of the paper's author(s). 


\title{
How will the COVID-19 pandemic affect the regions? A comparative analysis of the EU and ASEAN
}

\author{
Bruno Jetin
}

\begin{abstract}
:
The COVID-19 pandemic calls for a collective response at the global and regional level. Otherwise, some nations may be left behind and the potential for the contagion to return remains high. As advanced regional blocs, the EU and ASEAN have a major responsibility to their members for coordinating health protection measures and access to vaccines, maintaining the mobility of people and goods, and supporting their economy. The pandemic is therefore a test for regions. They must demonstrate that they are at least making national measures more effective. This paper seeks to determine whether the EU and ASEAN have passed the COVID19 test. It does so by analysing their responses in 2020 when the countries were hit by the first wave of contagion. The first section of the paper considers their attitude and action when the initial cases appeared in Europe and Southeast Asia in the early part of 2020. While the second section focuses on vaccines and the policies adopted in each region. The paper concludes that overall, the responses of the two regions to their COVID-19 test were late and insufficient.
\end{abstract}

Keywords: ASEAN; COVID-19; EU; Pandemic; Policy Responses

List of IAS Working Papers 
1. King, Victor T., Culture and Identity: Some Borneo Comparisons. Working Paper No. 1 Gadong: Institute of Asian Studies, Universiti Brunei Darussalam 2012.

2. Evers, Hans-Dieter and Solvay Gerke, Local Knowledge and the Digital Divide: Focus on Southeast Asia. Working Paper No. 2. Gadong: Institute of Asian Studies, Universiti Brunei Darussalam 2012.

3. King, Victor T., Borneo and Beyond: Reflections on Borneo Studies, Anthropology and the Social Sciences. Working Paper No. 3. Gadong: Institute of Asian Studies, Universiti Brunei Darussalam 2013.

4. King, Victor T., UNESCO in Southeast Asia: World Heritage Sites in Comparative Perspective. Working Paper No. 4. Gadong: Institute of Asian Studies, Universiti Brunei Darussalam 2013.

5. Purwaningrum, Farah, Knowledge Transfer Within an Industrial Cluster in the Jakarta Metropolitan Area. Working Paper No. 5. Gadong: Institute of Asian Studies, Universiti Brunei Darussalam 2013.

6. Evers, Hans-Dieter, Ndah, Anthony Banyouko \& Yahya, Liyana, Epistemic Landscape Atlas of Brunei Darussalam. Working Paper No. 6. Gadong: Institute of Asian Studies, Universiti Brunei Darussalam 2013.

7. Carnegie, Paul J., Is the Indonesian Transition a Model for the Arab Spring? Working Paper No. 7. Gadong: Institute of Asian Studies, Universiti Brunei Darussalam 2013.

8. Lian, Kwen Fee, Citizenship Regimes and the Politics of Difference in Southeast Asia. Working Paper No. 8. Gadong: Institute of Asian Studies, Universiti Brunei Darussalam 2013.

9. Purwaningrum, Farah, Ariff Lim, Syamimi, Evers, Hans-Dieter \& Ndah, Anthony Banyouko, The Governance of Knowledge: Perspectives from Brunei Darussalam and Malaysia. Working Paper No. 9. Gadong: Institute of Asian Studies, Universiti Brunei Darussalam 2014.

10. Facal, Gabriel, Hyper-centralization of Political Power and Fragmentation of Local Authority Networks in Banten (Indonesia). Working Paper No.10. Gadong: Institute of Asian Studies, Universiti Brunei Darussalam 2014.

11. Hussainmiya, B.A. and Mail, Asbol Haji, "No Federation Please-We Are Bruneians": Scuttling the Northern Borneo Closer Association Proposals. Working Paper No.11. Gadong: Institute of Asian Studies, Universiti Brunei Darussalam 2014.

12. Abdul Hakim, Mufidah. Pengangun as Ritual Specialist in Brunei Darussalam. Working Paper No.12. Gadong: Institute of Asian Studies, Universiti Brunei Darussalam 2014.

13. Bensaoud, Mariam. Between R2P and the ASEAN Way:The case of Myanmar's Cylcone Nargis. Working Paper No.13. Gadong: Institute of Asian Studies, Universiti Brunei Darussalam 2015.

14. Abdul Razak, Nurul Umillah Binti, Anuar, Adira Rehafizzan Binti, Pg. Mohd Sahar, Dk. Siti Nurul Islam Binti \& Matsuni, Nur Hidayah Binti. Domestic Maids in Brunei: A Case Study. Working Paper No.14. Gadong: Institute of Asian Studies, Universiti Brunei Darussalam 2015.

15. Ibrahim, Zawawi. From Island to Nation-state Formations and Developmentalism: Penan Story-telling as Narratives of 'territorialising space' and Reclaiming Stewardship. Working Paper No.15. Gadong: Institute of Asian Studies, Universiti Brunei Darussalam 2015.

16. Bui, Cuong The. Social Stratification in the Southeast Region of Viet Nam. Working Paper No. 16 Gadong: Institute of Asian Studies, Universiti Brunei Darussalam 2015.

17. Sagoo, Kiran. Reconsidering Ethnicity: Classification and Boundary Formation. Working Paper No. 17. Gadong: Institute of Asian Studies, Universiti Brunei Darussalam 2015. 
18. Ibrahim, Zawawi. Disciplining Rock Music and Identity Contestations: Hybridization, Islam and New Musical Genres in Contemporary Malaysian Popular Music. Working Paper No.18. Gadong: Institute of Asian Studies, Universiti Brunei Darussalam 2015.

19. Shui, Kong Ho. Digital Memoir of the South China Sea. Working Paper No. 19. Gadong: Institute of Asian Studies, Universiti Brunei Darussalam 2015.

20. Ullah, AKM Ahsan; Yusof, Yusnani Mohamed; D'Aria, Maria. How safe is Safe? 'Safe migration' in Southeast Asia. Working Paper No. 20. Gadong: Institute of Asian Studies, Universiti Brunei Darussalam 2016.

21. Oishi, Mikio. Co-existing Differences: Towards an East Asian Way Of Incompatibility Mangement. Working Paper No. 21. Gadong: Institute of Asian Studies, Universiti Brunei Darussalam 2016.

22. Carnegie, Paul J. Of Social Imaginary and Violence: Responding to Islamist Militancy in Indonesia. Working Paper No. 22. Gadong: Institute of Asian Studies, Universiti Brunei Darussalam 2016.

23. Rosidi, Imron. Being Active Consumers: Indonesian Muslim Youth Engaging With Korean Television Dramas. Working Paper No. 23. Gadong: Institute of Asian Studies, Universiti Brunei Darussalam 2016.

24. King, Victor T. Convergence and Divergence: Issues of State and Region in Tourism Development in Malaysian Borneo, Brunei Darussalam and Indonesian Kalimantan. Working Paper No. 24. Gadong: Institute of Asian Studies, Universiti Brunei Darussalam 2016.

25. Dhont, Frank, Marles, Jane E. \& Jukim, Maslin. Memories of World War II: Oral History of Brunei Darussalam (Dec. 1941-June 1942). Working Paper No. 25. Gadong: Institute of Asian Studies, Universiti Brunei Darussalam 2016.

26. Chu, Ta-Wei. Contestation between Riparian People and States: The Sesan River Hydropower Projects, Cambodia. Working Paper No. 26. Gadong: Institute of Asian Studies, Universiti Brunei Darussalam 2016.

27. Nugroho, S. Post-Authoritarian Discourses of "Indonesia" in Television Commercials. Working Paper No. 27. Gadong: Institute of Asian Studies, Universiti Brunei Darussalam 2016.

28. Hamdi, Muhammad Faiz Zul, Abdullah, Norhidayah, and Narudin, Hazimatula Diyana. Space, Place, and Identity: How Migration have Transformed Kampong Ayer. Working Paper No. 28. Gadong: Institute of Asian Studies, Universiti Brunei Darussalam 2017.

29. Chin, Wei Lee. Tourism, Communities, and Quality of Life Indicators in Bali. Working Paper No. 29. Gadong: Institute of Asian Studies, Universiti Brunei Darussalam 2017.

30. Jetin, Bruno. "One Belt-One Road Initiative" and ASEAN Connectivity: Synergy Issues and Potentialities. Working Paper No. 30. Gadong: Institute of Asian Studies, Universiti Brunei Darussalam 2017.

31. Maier, Hendrik M.J. Silent the Sea, Writing the Shores - Traveling over the South China Sea. Working Paper No. 31. Gadong: Institute of Asian Studies, Universiti Brunei Darussalam 2017.

32. Hoon, Chang-Yau. Between Hybridity and Identity: Chineseness as a Cultural Resource in Indonesia. Working Paper No. 32. Gadong: Institute of Asian Studies, Universiti Brunei Darussalam 2017.

33. Forbes, Vivian Louis. Re-framing the South China Sea: Geographical Reality and Historical Fact and Fiction. Working Paper No. 33. Gadong: Institute of Asian Studies, Universiti Brunei Darussalam 2017.

34. Oishi, Mikio. Absorbing External Shocks: ASEAN's Approach to Regional Stubility. Working Paper No. 34. Gadong: Institute of Asian Studies, Universiti Brunei Darussalam 2017. 
35. King, Victor T. Emerging Tourisms and Tourism Studies in Southeast Asia. Working Paper No. 35. Gadong: Institute of Asian Studies, Universiti Brunei Darussalam 2017.

36. Hassan, Noor Hasharina. Housing Matters: The Value of Housing. Working Paper No. 36. Gadong: Institute of Asian Studies, Universiti Brunei Darussalam 2017.

37. Rahman, Md Mizanur. Beyond Skilled Immigration: The Making of New Immigrant Enterprises in Canada. Working Paper No. 37. Gadong: Institute of Asian Studies, Universiti Brunei Darussalam 2017.

38. Ibrahim, Faizul H. Kitchen Anthropology: Understanding Food, Cooking and Eating in Bruneian MiddleClass Families. Working Paper No. 38. Gadong: Institute of Asian Studies, Universiti Brunei Darussalam 2018.

39. Haji Mohamad, Siti Mazidah. The Performance of Religiosity on Social Media: Three Future Research Directions. Working Paper No. 39. Gadong: Institute of Asian Studies, Universiti Brunei Darussalam 2018.

40. King, Victor T. Tourism and Leisure in Thailand: Erik Cohen and Beyond. Working Paper No. 40. Gadong: Institute of Asian Studies, Universiti Brunei Darussalam 2018.

41. Munakata, Mizuki \& Franco, F. M. A comparative analysis of the Portrayal of Rainforests and People in Tourism Promotional Videos. Working Paper No. 41. Gadong: Institute of Asian Studies, Universiti Brunei Darussalam 2018.

42. Sahrifulhafiz, Nur Shawatriqah Binti Hj Md. \& Hoon, Chang-Yau. The Cultural Identity of the ChineseMalays in Brunei: Acculturation and Hybridity. Working Paper No. 42. Gadong: Institute of Asian Studies, Universiti Brunei Darussalam 2018.

43. Knudsen, Magne. Agrarian transition and smallholder success through local networks: A case study from Mindanao. Working Paper No. 43. Gadong: Institute of Asian Studies, Universiti Brunei Darussalam 2018.

44. Huesca, Eliseo Jr. \& Fiesta, Margie D. Everyday Voices in Marginal Places: Political Anxiety, Resistance, and Mass Support under Duterte's Martial Law. Working Paper No. 44. Gadong: Institute of Asian Studies, Universiti Brunei Darussalam 2018.

45. Abdul Samad, Nur E'zzati Rasyidah. Malay Traditional Marriage Ceremonies in Brunei: Continuity and Change. Working Paper No. 45. Gadong: Institute of Asian Studies, Universiti Brunei Darussalam 2018.

46. Chattoraj, Diotima \& Gerharz, Eva. Difficult Return: Muslims' ambivalent attachment to Jaffna in PostConflict Sri Lanka. Working Paper No. 46. Gadong: Institute of Asian Studies, Universiti Brunei Darussalam 2019.

47. Samad, Nur E'zzati Rasyidah binti Haji Abdul. Malay Traditional Marriage Ceremonies in Brunei: Continuity and Change. Working Paper No. 47. Gadong: Institute of Asian Studies, Universiti Brunei Darussalam 2019.

48. Jaidin, Izzati. Ageing and Malay Muslim Women in Brunei. Working Paper No. 48. Gadong: Institute of Asian Studies, Universiti Brunei Darussalam 2019.

49. King, Victor T. The Construction of Southeast Asia as an Academic Field of Study: Personages, Programmes and Problems. Working Paper No. 49. Gadong: Institute of Asian Studies, Universiti Brunei Darussalam 2019.

50. Haji Kifli, Hajah Siti Norfadzilah Binti. Halal Certification in Brunei. Working Paper No. 50. Gadong: Institute of Asian Studies, Universiti Brunei Darussalam 2019. 
51. Belezaire, Cordelia. Rethinking the Limits of Public Service Labour Casualization in Developing States. Working Paper No. 51. Gadong: Institute of Asian Studies, Universiti Brunei Darussalam 2019.

52. King, Victor T. 'Wild Borneo': Anthropologists at War in the Rainforest. Working Paper No. 52. Gadong: Institute of Asian Studies, Universiti Brunei Darussalam 2020.

53. Kwen Fee, Lian. Retracing the Political Construction of Race and Ethnic Identity in Malaysia and Singapore: Career of a Concept. Working Paper No. 53. Gadong: Institute of Asian Studies, Universiti Brunei Darussalam 2020.

54. Wahab, Mahfuzah Abd. Performative Mimicry and Postcolonial Exoticism: A Re-Politicising of the Female Body in the Work of Cheryl Lu-Lien Tan and Amir Falique. Working Paper No. 54. Gadong: Institute of Asian Studies, Universiti Brunei Darussalam 2020.

55. Carnegie, Paul J. On Constitutions and Power:An Anatomy of Indonesian Reforms 1999-2002. Working Paper No. 55. Gadong: Institute of Asian Studies, Universiti Brunei Darussalam 2020.

56. Hazimah, Mahirah Nazatul and Kwen Fee, Lian. The Iban of Melilas, Ulu Belait: From Migrants to Citizens. Working Paper No. 56. Gadong: Institute of Asian Studies, Universiti Brunei Darussalam 2020.

57. Chan, Jennifer, K.L. and King, Victor T. Covid-19 and Tourism in Southeast Asia. Working Paper No.57. Gadong: Institute of Asian Studies, Universiti Brunei Darussalam 2020.

58. Ibrahim, Zawawi. The Anthropology of Remembering and Memory as Ethnography: Reflections on a Fishing Village and Firth's Malay Fishermen Working Paper No.58. Gadong: Institute of Asian Studies, Universiti Brunei Darussalam 2020.

59. Franco, F. Merlin, Samuel, Godson, Francis, T. Mutualism between Humans and Palms: The Curious Case of the Palmyra Palm (Borassus flabellifer L.), and its Tapper. Working Paper No.59. Gadong: Institute of Asian Studies, Universiti Brunei Darussalam 2020.

60. Tong, Chee Kiong and Lee, Cheuk Yin. From Periphery to Center to Periphery: Chinese Studies in Southeast Asia, 1960-2000. Working Paper No.60. Gadong: Institute of Asian Studies, Universiti Brunei Darussalam 2020.

61. Rosdi, Ade Roddiane bin Haji Mohd and Carnegie, Paul J. Illegal Fishing and the Challenges of Maritime Co-ordination in Brunei's EEZ. Working Paper No. 61. Gadong: Institute of Asian Studies, Universiti Brunei Darussalam 2021.

62. Fadzillah, T.P.M. Adi Nabil and Hoon, Chang-Yau. Changing Notions of Masculinity among Young Malay Men in Brunei Darussalam. Working Paper No. 62. Gadong: Institute of Asian Studies, Universiti Brunei Darussalam 2021. 


\title{
How will the COVID-19 pandemic affect the regions? A comparative analysis of the EU and ASEAN
}

\author{
Bruno Jetin
}

\section{Introduction}

The COVID-19 pandemic is a political challenge to regions such as the European Union (EU) and the Association of Southeast Asian Nations (ASEAN). ${ }^{1}$ During times of crisis, regions can demonstrate that a collective response brings a more effective solution to the people's problems and suffering than state intervention on a purely national scale. It is also at this moment that large powers like China, Japan and the USA can show their capacity to provide financial support and practical aid to gain influence and leadership. However, the EU and ASEAN, the two most emblematic regions in the world, seemed initially unable to meet the challenge. During the first months of 2020, the most effective measures have been taken unilaterally at the national level in the absence of regional coordination.

The pandemic is also an economic challenge. It has disrupted the Global Value Chains (GVCs) of numerous manufactured goods and services, underpinning most Asian and European trade (Jetin, 2018). It was notably the case for food, medicine and personal protective equipment (PPE). This resulted in criticisms to overstretched GVCs (Stiglitz, 2020), to an overdependence on China (Politi, 2020), and to a plea for relocation of critical goods in the home country (Abboud \& Peel, 2020; Michel, 2020; Sevastopulo \& Williams, 2020). Faced with the total shortage of PPE, several countries have even begun to produce them locally, revealing unsuspected internal resources and innovation capabilities at the most decentralised level. In some countries, the lockdown has also induced a reorganisation of small and medium enterprises (SMEs), which started to sell their products directly to local customers, usually with the help of some online applications. In short, the COVID-19 could tip the scales in favour of

\footnotetext{
${ }^{1}$ As Söderbaum (2012: 14) notes, "most scholars engaged in the contemporary debate agree that there are no natural or 'scientific' regions and that these definitions vary according to the particular problem or question under investigation." As this paper considers the responses to the COVID-19 pandemic, its operational definition of regions is an "inter-state or policy-driven framework", that focuses on regional organisations such as the EU, ASEAN, and ASEAN+3. In the latter case, it means that the region goes beyond the territory of Southeast Asia and include East Asian countries.
} 
the region and the local economy. Proximity is preferred to distance because it seems to correspond better to a need for security (Enderwick \& Buckley, 2020).

How far will the pendulum swing? Does this return to the national precinct herald a prolonged decline of the region? Or, alternatively, is the COVID-19 crisis an opportunity for its renewal?

This paper attempts to answer these questions by looking at the EU and ASEAN's responses to COVID-19. Firstly, we argue that the two regions were initially taken aback by the pandemic's first wave, leaving the nation-states as the primary, if not the sole actor at the helm. Secondly, the regions adopted specific responses that expressed in the open their institutional differences. After a couple of months, the European Union has been able to take a range of measures that complement and increase national policies' effectiveness, while ASEAN struggled to go beyond discussion and information sharing. The latter only plans to do so by calling on big regional powers, China, Japan, and South Korea, which are part of the ASEAN +3 group. This reflects another distinctive trait of the EU and ASEAN on top of their institutional alterity. While the EU dominates the whole of Europe, even after Brexit, ASEAN is only a minor part of Asia, both economically and demographically.

Within ASEAN + 3, China largely dominates economically, but Japan and South Korea still retain a strong economic power. This implies that ASEAN must be part of a complex diplomatic game when it comes to these three countries and asks them to fund its own policies. It explains that, while the COVID-19 has sharpened the conflicting relationship between China and the EU, which qualified the former a "systemic rival" in March 2019 (Kahn \& Prin, 2021), ASEAN has had a more accommodating relationship with China.

It means that any comparative analysis of the two regions must include the political economy and the geopolitical context and not be confined to a comparison of institutions. In this perspective, the paper is organised as follows. Section 1 compares the EU and ASEAN policies adopted to fight the pandemic. Section 2 focuses on the geopolitics of vaccine and how the two regions tried to secure vaccines for their respective population. Our conclusion is that the EU failed the COVID-19 test, because it was not prepared to contain the first and second waves of contagion, and because it was not able to provide enough vaccines quickly. Paradoxically, ASEAN did not fail as much because no one expected that it would play a primary role. 


\section{EU and ASEAN Responses to the Pandemic}

The EU is by far the most advanced political and economically integrated region of the world. It is the only one where decisive elements of national sovereignty have been transferred to regional institutions, which have a real power of initiative and decision. European citizens have a complex and varied relationship with the EU, ranging from strong support to harsh criticism. But in any case, the EU is part of their daily life, and in times of crisis, they expect it to provide concrete solutions, just like their government.

ASEAN is a far less integrated region on political and economic accounts. It works as an institutional space where governments can exchange information, discuss to achieve consensus and, if so, coordinate their action and implement common decisions. Although ASEAN seeks to promote a regional identity in which grassroots citizens can relate to, the fact remains that their hopes in the region are relatively low. They do not expect ASEAN to play a leading role in a collective fight against the virus (Beeson, 2020: 247). Nevertheless, Southeast Asians are eager to see ASEAN play an active and concrete role, and the pandemic is an opportunity for ASEAN to prove its usefulness in times of crisis. This context allows us to understand better how the inhabitants experienced the crisis.

\section{The European Union Tries to Survive the COVID Tsunami}

Europe became really aware of the pandemic when in February 2020, Italy was the first country to register a high number of cases saturating hospitals' reception capacities. On 28 February 2020, Italy activated the "EU Civil Protection Mechanism", part of the Commission's Emergency Response Coordination Centre ${ }^{2}$ (European Commission, 2020a). The mechanism relies on EU countries to volunteer help. None of the 26 other European country members stepped forward as they were finally discovering that their own hospitals could be overwhelmed and that there was a general shortage throughout Europe of PPE (Herszenhorn \& Wheaton, 2020). Worse, Germany, France and the Czech Republic imposed export restrictions to PPE in violation of the principle of the free flow of goods, a core element of the EU single market (Guarascio \& Blenkinsop, 2020). Some countries also decided to close their border unilaterally, which was the source of disorder and contravened to the Schengen Convention that guarantees people's free movement within the EU. Likewise, member

\footnotetext{
2 "Upon request, the European Commission, through its Emergency Response Coordination Centre, provides assistance such as coordinating and co-financing the delivery of personal protective material and other assistance, repatriation flights to bring back stranded citizens from outside Europe, and the transport of medical teams from one country to another" (European Commission, 2020a).
} 
countries have decided to impose lockdown on their territory with different rules and durations, while their neighbours refused to impose any form of confinement. Even protective measures, such as wearing a mask, have not been harmonised, undoubtedly due to their shortage, which lasted for several months. The rise of national governments to the forefront has come at the cost of disorder and inefficiency. Worse, member countries have competed for the import of PPE from China. Sometimes, within the same country, local authorities have competed to import PPE, or have clashed with their national government. All these non-cooperative behaviours reveal the limit of a European integration model based more on competition than solidarity. It also results from the priority given to economic rather than to social issues. For instance, the Maastricht Treaty and later the Amsterdam Treaty resulted in adopting a single currency, a single monetary policy and a central bank, and severe restrictions imposed on the national fiscal policy. These are decisive transfers of sovereignty to the European institutions. Public health, which is also crucial for human life, is covered in these treaties but has not been the subject of a transfer of sovereignty to the European institutions. The EU has limited powers and serves to complement national policies, the central role being played by governments of member countries (Papageorgiou \& Melo, 2020). Organising and delivering healthcare is their responsibility, while the EU helps them achieve shared objectives, generate economies of scale, pool resources, and tackle common challenges such as pandemics. The EU has set up specialised agencies such as the European Medicines Agency (EMA) and the European Centre for Disease Prevention and Control (ECDC) (European Commission, 2020b). So, on paper, the responsibilities were clear, and the EU should have been well-prepared to tackle the COVID19.

In practice, things did not go as planned. The priority is given to the economy, and in particular to the budget surplus target, has led to a permanent reduction in public spending, especially in the health budget. In most countries, hospitals were understaffed and underequipped. They were quickly overwhelmed by the pandemic. The obsession with permanent cost-cutting led most countries to reduce their PPE stocks to a minimum in the preceding years. As a result, the EU Commission's Emergency Response Coordination Centre had not much to coordinate because there was a general scarcity of medical staff, beds in hospitals, and PPE stocks. Worse, the EU failed in its critical role of detection and identification of health threat, early warning, and notification. It wasted a precious time, between January and March 2020, to realise the gravity of the crisis that could have been used to put in place policies to meet the challenge (Herszenhorn \& Wheaton, 2020). As a result, the EU was among the most hardly hit by the pandemic. Table 1 shows that, except for Germany, the case fatality rate was far above 
the world average (2.2) for several European countries. Their reported cases per 100,000 inhabitants are far above that of Asian countries.

It is only after the outbreak of the pandemic that the EU started to play a positive role. The EU established a "European reserve of additional capacities" (the 'rescEU reserve'), distributing tens of thousands of protective masks, medical gloves and 30 ventilators. They were coming from the strategic rescEU distribution centres hosted by then 6 EU Member States and given to countries who needed them most. While these efforts are commendable, the quantities involved were extremely modest in relation to the needs and were more symbolic than effective. Starting in April, the EU Civil Protection Mechanism was finally able to send and finance a team of doctors and nurses from Romania and Norway to Italy. Various actions of solidarity are documented on the European Commission's website (European Commission, 2020a), which show the dedication of all staff involved. However, it was too little too late and drawing the lessons of the past months the EU Commission proposed to build "a European Health Union to reinforce the EU's resilience for cross-border health threats" (European Commission, 2020c). Concretely, the European Health Union would be the outcome of a strengthening of the mandate of the European Centre for Disease Prevention and Control (ECDC), and an extension of the mandate of the European Medicines Agency (EMA). Among the proposals, the ECDC would have the capacity and the power to declare a pandemic in the EU, even in the absence of such a declaration by the WHO. It is a pivotal proposal to avoid wasting precious time and protect the EU from the consequences of the WHO's politicisation. A third proposal is the strengthening of the "Health Security Committee", an informal advisory group of health ministers, where EU member states consult each other in liaison with the Commission. The Health Security Committee would help the Commission to adopt "recommendations" that would translate into actual "implementable measures" that member states would "commit to implement". It is not yet clear if member states will actually commit to implementing these recommendations because it involves a transfer of power that has not been readily discussed and approved. But it clearly shows that the Commission is aware that the EU has not met so far, the European citizens' expectations.

Outside the strict health field, the EU has adopted a series of economic measures to support the economy and reduce the economic crisis's social impact. On 23 April 2020, the Eurogroup agreed on a package of $€ 540$ billion. $€ 100$ billion in the form of loans to assist workers in keeping their jobs; $€ 200$ billion provided by the European Investment Bank to support SMEs; and finally, €240 billion from the European Stability Mechanism to support the healthcare system of member states. The European Central Bank provided a total of $€ 870$ to 
local banks. A new recovery instrument proposed by the Euro Commission called the "Next Generation EU" was adopted after harsh negotiations between the so-called "frugal countries" and the rest of the member countries (Brundsen \& Flemming, 2020). It will rise $€ 750$ billions of joint EU debt.

This agreement gives Brussels unprecedented powers to borrow $€ 750$ billion on the markets and hand it out as budgetary support to member states to invest in their economy as part of their recovery efforts. It is a historic decision because it is the first time Germany accepts the issuance of common EU debt, which it has obstinately refused, even at the onset of the great recession of 2008-09 and the collapse of the Greek economy. More, a new multi-annual budget of $€ 1.8$ trillion landmark post-pandemic recovery package was accepted on 11 December 2020. This came after months of conflict with Poland and Hungary who had vetoed the agreement reached in July 2020 for fear that under new rules, the EU funding could be held back when countries endanger the bloc's budget by violating the rule of law. (Peel et al., 2020).

This economic mobilisation, which sees the European Union borrowing and investing enormous sums to support health policy and the economy in crisis, is truly unique to the EU and unparalleled in the world. It shows that the EU fared better in response to the pandemic than in its prevention.

Opinion polls reflect this feeling. According to a pan-European survey conducted in June 2020 by the European Council on Foreign Relations (ECFR), Europeans are "traumatised" and think that "their country was largely left to fend for itself" and "was their most helpful ally" in dealing with the pandemic (Dennison \& Zerka, 2020: 5). The EU came second only in Poland among the 27 members. In Spain, Denmark, and Sweden, it is the World Health Organisation (WHO). In Italy, China is the second most common response, because Italy received high-profile Chinese assistance in the form of medical equipment, expertise, and research support when no European country came to its aid. In all countries, the perception of the EU institutions has deteriorated. However, respondents are willing "to give EU institutions the benefit of doubt on the planned economic recovery, despite feeling disappointed with these institutions' response to the health crisis" (Dennison \& Zerka, 2020: 6). This is confirmed by a later poll commissioned in October 2020 by the European Parliament. The survey reveals that "two-thirds of respondents agree that the EU should have more competences to deal with crises such as the Coronavirus pandemic". Another significant result is that "citizens support a larger EU budget, and they want this money spent first on public health (54 percent), then economic recovery (42 percent) and finally climate change (37 percent)" in that order (European Parliament, 2020). 
In short, Europeans' opinion reveals that they have been disappointed by the European Union, but that they want it to do more and better during the second wave of the pandemic in the autumn of 2020 .

\section{The ASEAN Way of Coordinating Challenged by the COVID Tsunami}

Like the EU, ASEAN was initially slow to respond to the pandemic. Given its proximity to China and the intense relationships Southeast Asia entertains with its powerful neighbour, ASEAN was among the first regions to be hit. Wuhan went into lockdown on 22 January 2020, and 41 days later, on 29 February, China managed to flatten the curve. The WHO declared a state of global pandemic on 11 March 2020. Cases started to grow exponentially in Southeast Asia since then (Kimura et al., 2020). According to the authors, who are well-known economists of the Asia-Pacific region, and regular contributors to the Economic Research Institute for ASEAN and East Asia (ERIA), the period that started with Wuhan's lockdown $(22 / 01 / 20)$ to when China flattens the curve $(29 / 02 / 20)$ was critical and could have been better used. As Kimura et al. (2020:13) note:

\footnotetext{
"In the first phase, there was no common strategy in the region. There could have been greater coordination between ASEAN member states and East Asian countries to mitigate and isolate the movements of workers and tourists from China, even though some economies had not yet experienced infection. At this stage, ASEAN could have shared more information with business and workers. Efforts could have been made to manage people's movements and stockpile the necessary healthcare and equipment. During this phase, there could have been more healthcare mitigation (hospital isolation and observation of identified cases and treatment of critical cases), and social isolation, (identification, (testing), isolation (managed social distancing and self-isolation) and implementation (enforcement)), which although costly to business, would have had benefits for human well-being and reducing fatalities in the longer term."
}

Singapore and Vietnam were the only countries to respond in early February by taking extensive monitoring measures, contact tracing and isolation. They were the first to ban travel to and from China (Saha, 2020). All the other members adopted unilaterally similar measures at a later date and in a disorderly manner. They implemented entry bans and quarantine between $22^{\text {nd }}$ and $31^{\text {st }}$ March for all travellers (CSIS, 2020). ASEAN's first response was to convene a Special ASEAN-China Foreign Ministers’ Meeting in Vientiane on 20 February “which agreed 
to strengthen cooperation to fight the disease without specifying any concrete actions" (Menon, 2020: 123-124). Three weeks later on 13 March, the ASEAN Senior Health Officials met online. Participants shared updated information, discussed capacity needs and gaps of the member states. They also stressed the importance of using the existing seven regional health mechanisms put in place by the ASEAN Health Sector Cooperation since the previous pandemics like the SARS outbreak in 2003, the H1N1 in 2009, the Ebola virus in 2014, the MERS-COV in 2015 and the Zika virus in 2016 (ASEAN, 2020). ${ }^{3}$

The ASEAN Emergency Operations Centre Network for public health emergencies (ASEAN EOC Network) has shared daily publicly situational updates on ASEAN's contamination, for use by country members, and to raise awareness on social media for prevention and containment. The ASEAN BioDiaspora Virtual Centre provides national risks assessments, readiness, and response planning efforts.

The ASEAN Senior Health Officials also decided to convene the ASEAN Health Ministers meeting and invite them to meet with other Dialogue Partners such as the Plus Three Countries (China, Japan, South Korea). This last meeting called the "Special ASEAN Plus three Summit on Coronavirus Disease" was held online one month later on 14 April. It created a "COVID-19 Response Fund", without additional funding, and a "Regional reserve of essential medical supplies".

It is hard to assess how this online activity of exchange of information and coordination attempts, which is dubbed "ASEAN online" (Dalpino, 2020: 53), translates into effective regional responses. Not that information sharing, and consultation should be underestimated. Malaysia's lockdown in March 2020, was decided unilaterally and implemented immediately with a direct effect on the 300,000 Malaysians who work in Singapore and commute daily across the border between the two countries. Singapore had to arranged temporary accommodation for them (Menon, 2020). This added economic and social costs to workers and employers, which could have been avoided had ASEAN played an upstream coordination role.

\footnotetext{
3 These mechanisms are: 1 . The ASEAN Plus Three Senior Officials Meeting for Health Development (APT SOMHD) currently chaired by Cambodia. 2. The ASEAN Emergency Operations Centre Network for public health emergencies (ASEAN EOC Network) led by Malaysia. 3. The ASEAN Plus Three Field Epidemiology Training Network (ASEAN+3 FETN) currently chaired by Malaysia and coordinated by Thailand. 4. The ASEAN BioDiaspora Virtual Centre for big data analytics and visualization (ABVC) led by Philippines. 5. The ASEAN Risk Assessment and Risk Communication Centre (ARARC) led by Malaysia. 6. The Public health laboratories network under the purview of ASEAN Health Cluster 2 on Responding to All Hazards and Emerging Threats. 7. The Regional Public Health Laboratories Network (RPHL) led by Thailand through the Global Health Security Agenda platform (ASEAN, 2020).
} 
However, ASEAN and the EU could not prevent its members' rush to take a haphazard closure of borders.

Similarly, the closure of borders has blocked up to about ten million undocumented migrant workers in the respective ASEAN member countries, among which seven million originate from ASEAN (Ducanes et al., 2020). Their already poor living conditions worsened, and their health deteriorated. They are usually denied social protection and access to health services and are the most at risk of contamination. It created potential clusters of undetected outbreaks of the epidemic as epitomised by the case of Singapore. Singapore was one of the first members to take drastic measures against the pandemic. Nonetheless, it recorded one of the highest rates of contamination in ASEAN, with 94 percent of the cases being migrant workers making homes in packed dormitories (Iwamoto, 2020). The Singapore government decided to test all of the 300,000 migrant workers and treat them in hospitals. However, their complete isolation in dormitories is endangering their mental health leading self-harm incidents and suicide attempts. In several other ASEAN countries, migrant workers live in similar conditions but do not have access to health services. Some ASEAN member states have decided on their own initiative to repatriate documented migrant workers from other ASM back to their respective home countries. "With movement restrictions from March to May, it was estimated that 150,000 migrant workers from Myanmar, 50,000 from Cambodia, and 60,000 from Laos returned home after losing their jobs in Thailand.

Similarly, about 40,000 migrant workers from Thailand and 12,000 from Indonesia went back home from Malaysia. More than half a million overseas Filipino workers have been displaced from their jobs as of October. Of these, over 300,000 have returned home (Ducanes et al., 2020). But ASEAN should have organised a regional response to make sure that no one is excluded. In Europe, the EU has financed up to 75 percent of EU citizens' repatriation. However, the vast majority of migrants are undocumented, and they were, like other minority groups, often left behind (Virgil \& Lie, 2020). The situation is no better in Europe where millions of undocumented migrants have been living for many years, in addition to the hundreds of thousands of new migrants gathered in makeshift camps without any access to health care.

If information sharing and coordination are necessary, it is clearly not enough. Public policies initiated and funded by the region are essential to cope with a crisis of the magnitude of the COVID-19 pandemic. In this respect, the difference between the EU and ASEAN is glaring. While the EU is an organisation with a sizable budget, ASEAN is an intergovernmental body with no significant financial resources. Although ASEAN includes two high-income 
countries, Singapore, and Brunei, they are far too small to fund any common policies at the regional level. The only vast country, Indonesia, which has the largest population and the largest GDP of Southeast Asia, is too poor to finance regional policies at a large scale. Indonesia had been upgraded by the World Bank in July 2020 to an upper-middle-income economy after more than two decades in the lower-middle-income group. However, the pandemic is reversing "two decades of steady economic growth marked by declining poverty rates and the rise of a middle class." and the country could fall back to its previous group (Maulia \& Damayanti, 2020). Other upper-middle-income countries like Malaysia and Thailand and soon Vietnam, do not have the financial clout to be large contributors. In any case, there is no political will to delegate elements of sovereignty to a supranational body, which could manage a budget.

Instead, ASEAN creates and manages special funds, like the COVID-19 Response Fund, for which ASEAN asks the contribution of the Dialogue Partners such as the Plus Three Countries, or Australia, India, the US, and the EU. The COVID-19 Response Fund was formally established at the 37th ASEAN Summit on 12-15 November 2020 and received at that date contributions of AMS like Vietnam (\$5 million) or Singapore (US\$100,000). Together, Japan, China, and South Korea have so far contributed more than \$60 million and India, \$1 million. Australia announced a \$422 million injection of aid in various forms as well as the USA with $\$ 87$ million (Strangio, 2020a). The $37^{\text {th }}$ summit also agreed to set up the ASEAN Regional Reserve of Medical Supplies which also received PPE from donor countries. The Response fund budget will grow, but one can see that the amount involved is minimal compared to the amount spent by the EU, although the population of the two regions is of similar size. The $37^{\text {th }}$ summit also approved "the Comprehensive Recovery Framework for ASEAN and Action Plan" which has three main points: reopen, recovery and self-reliance (Viet, 2020). Like the EU after the shock of the first wave, ASEAN may prove more useful for the recovery of the economy, which needs coordination, particularly for the reopening of air transport and regional trade. The latter was deeply affected by the closure of borders and protectionist measures like export restrictions taken by some member countries. However, one of the critical issues that will be decisive for the two regions' legitimacy will be the vaccine supply. In this domain, the action of the EU and ASEAN is radically different. 


\section{Global Vaccines Politics at Play}

The pandemic has called for greater security of supply for critical goods and services, which seems to be better served at the regional level. Production and distribution may be more manageable and robust. This renewed interest for proximity and nearness may be pushing the world towards more regionalisation (Enderwick \& Buckley, 2020), which is perceived as an alternative to the excess of globalisation. One can observe the premises of this growing regionalisation in maritime transport, which forwards 80 percent of international trade, where there has been a recent increase of traffic at the regional level (Pooler \& Hale, 2020). It remains to be seen whether the "strategic autonomy" of regions that the EU wants to promote will induce a significant onshoring or regionalisation of the GVCs in food, medicines, and PPE. Multinational firms wish to retain the right to decide where they localise their production and distribute their products and services worldwide and refuse any interference of the EU or its member states (Khan, 2020).

Nonetheless, as far as vaccines are concerned, the logic is entirely different. Because of the urgency to vaccinate as many people as possible across the world in the shortest delay, "the COVID-19 vaccine is going to be the biggest product launch in the history of mankind", much larger than the launch of a new smartphone, and monopolising the global airfreight capacity for a long time (Hailey, 2020). Fifteen thousand air flights are needed to vaccinate billion 7.8 people. Even if half of the doses are transported by land in the advanced countries, where most of the vaccines will be produced, the remaining flights to organising remains a challenge in times of pandemic and mobility restrictions. Not to mention the difficulties of distribution within countries because the new vaccines have more complex storage requirements (such as low temperature) and handling and administration. For instance, it explains that in the USA, the vaccination targets had not been met in December 2020, although there was no shortage of vaccines (Stacey, 2020). To meet this challenge, governments must intervene to make sure that there are no gaps in the global supply chains and coordinate efficiently all the public authorities involved at the national and local levels.

Additional complexity comes from the competition between big powers to secure vaccine doses for their population and between multinational pharmaceutical firms which play their own game to maximise their profit.

Due to its global nature, the pandemic calls for a worldwide response. The United Nations is backing the "Global Alliance for Vaccines and Immunisation" (GAVI, the Vaccine Alliance), a public-private organisation created in 2000, which co-led with the World Health Organisation and the "Coalition for Epidemic Preparedness Innovations" (CEPI), the COVAX 
Facility. COVAX aims to accelerate the development and manufacture of a wide range of COVID-19 vaccine candidates, negotiate their pricing and guarantee their fair distribution to all participating countries, regardless of income levels. The objective is to provide 2 billion COVID-19 vaccinations by the end of 2021, which should be enough to protect high risk and vulnerable people, as well as frontline healthcare workers. GAVI has created on 4 June 2020, a funding instrument, the "COVID-19 Vaccines Advance Market Commitment" (COVAX AMC), "to give access to 92 low- and middle-income countries in the COVAX Facility, enabling access to donor-funded doses of safe and effective COVID-19 vaccines, and making sure the most vulnerable in all countries can be protected in the short term, regardless of income level." (GAVI, 2021) The success of COVAX depends on the participation of high-income "self-financing" countries which pay to buy vaccines from the facility, thereby subsidising 92 so-called "funded" countries. It is the only genuinely global initiative which guarantees the safety of the vaccines approved, high volumes to manufacturers for their vaccines candidates before they are licensed, and international protection for rich and poor countries, which is the only way to avoid a resurgence of the pandemic. The following solidarity principle establishes the fairness of the distribution:

\footnotetext{
"Even though self-financing participants can request for enough doses to vaccinate between $10-50 \%$ of their population, no country will receive enough doses to vaccinate more than $20 \%$ of its population until all countries in the financing group have been offered this amount." (GAVI, 2021)
}

COVAX has failed to build momentum, and the three leading institutions were forced to postpone several times the limit to join the initiative. In October 2020, $\$ 2$ billion had been painstakingly raised, while $\$ 35$ billion were deemed necessary to buy sufficient volumes to vaccinate the world's population (Jack, 2020). Several reasons are given to explain these difficulties, such as the lack of flexibility of the funding instrument and purchasing contracts, and the capacity to reach the most vulnerable population. However, the most profound reason is "vaccine nationalism" (Jack, 2020). Many high-income countries joined late and preferred to strike their own exclusive arrangements with vaccine providers before. The EU, for instance, agreed to contribute $€ 500$ billion to COVAX (European Commission, 2020d) but prefer not buying shots through it because it does not want to have their supplies limited to 20 percent of their population. The USA and Russia did not join the COVAX initiative, and China joins only on 9 October after long hesitations, without giving the details of its contribution (Adlakha, 
2020). The priority given to national interest would not be an issue if there were enough production capacities of vaccines worldwide. However, the scramble of high-income countries (US, Canada, UK, EU, Japan) to secure large volumes of doses for their population creates a global shortage. According to a New York Times analysis of data on vaccine contracts collected by Duke University, UNICEF and Airfinity, a science analytics company, "if all the doses they have claimed are delivered, the European Union could inoculate its residents twice, Britain and the United States could do so four times over, and Canada six times over" (Twohey et al., 2020). In the meantime, COVAX struggles to order vaccines and low- and middleincome countries have to queue up to receive vaccines probably at the end of 2021. It explains why at the G20 summit in November 2020, "the G20 leaders skirted the question of how many doses they would reserve for their populations and how many they would release to the COVAX scheme" (Giles, 2020). Worse, to cut cost France envisaged that the EU could donate directly 5 percent of the 1.3 billion doses it has ordered, using COVAX to identify the receiving countries, but undercutting COVAX by not giving them to the distribution scheme co-led by the WHO (Guarascio, 2020). It would apply to 100 million optional additional Pfizer vaccines, "without any guarantee though on the timing of these deliveries".

In this global context, where the logic of every man for himself prevails, one could envisage that the region could maintain a principle of solidarity, partly compensating for the egoism existing at the global level. As we shall see, the EU and ASEAN do not play the same role in this respect, as they do not have the same mandate, responsibilities, and financial power. The EU has implemented a regional policy to provide vaccines to its member states, while ASEAN has not, leaving its member states on their own to decide for their best option: ordering directly from a pharmaceutical company for those who can, developing their own vaccines, or joining the COVAX scheme for those who do not have other choices.

\section{Vaccination Campaign: A Missed Opportunity for the EU}

The European Commission presented on 17 June 2020 a "European Vaccines Strategy" to accelerate the development, manufacturing, and deployment of effective and safe vaccines against COVID-19. It works basically at two levels. Firstly, it finances the development of vaccines and invests in the production facilities in return for the right to buy a specified number of vaccine doses in a given timeframe. Secondly, the European Medicines Agency (EMA) evaluates and approves the vaccines once they are ready. The European Commission makes sure that all its members have fair access to the doses proportionate to its share of the European population. According to Stella Kyriakides, Commissioner for Health and Food Safety, the 
Commission has "concluded six vaccine agreements so far. This is a clear demonstration of the European Health Union in action: a European Union that delivers tangible results for its citizens and a blueprint for our cooperation in the area of health in the future" (European Commission, 2020e). In summary, the EU plays a primary role in vaccines, a critical issue that polarises all attention and hopes at the time when a second wave hit Europe at the end of 2020.

This is a decisive opportunity for the European Union to restore its image and gain legitimacy on the critical issue of vaccination. This opportunity has been wasted because Europeans have had to observe the glaring inadequacy of available doses. On 31 December 2020, 132,000 Germans, 300 French and zero Dutch had been vaccinated, to be compared with 794,000 Israelis and 2.8 million Americans. To top it all off, the UK, which had just concluded the Brexit agreement, had by that date vaccinated 945,000 people. The reason for this failure is in part the unpreparedness of the national authorities. However, the responsibility of the European Commission is also called into question. Not only the BioNTech and Pfizer vaccine has been approved lately by the European Medicines Agency (EMA), but the EU appears to have bought too little. The European Commission did not prioritise Pfizer/BioNTech and Moderna, which were the first to be ready. The EU waited until 11 November to place an order of 300 million doses to Pfizer/BioNTech although the company had announced that it was completing phase 3 of trials two days before. The EU Commission has even turned down their proposals for hundreds of millions of more vaccine doses that were lacking in December 2020. The reason could be that France pushed hard to protect the interest of the French company Sanofi, which had received in August 2020 an option for an order of 300 million doses although its vaccine had not even passed the phase 1 of the test successfully (Schulz et al., 2020). Uğur Şahin, chief executive of BioNTech, confirmed that the EU has been too hesitant and refused to order more vaccines from Pfizer/BioNTech and Moderna at the time when capacities of production were available "partly because the European Union isn't directly authorised, and the member states have a say. In a negotiation ... it can take time" (Chazan et al., 2021). Whatever the exact reason is, the incapacity of the EU to deliver doses in sufficient quantity to vaccines rapidly around $70 \%$ of the population, which is the threshold of herd immunity, turned into a political disaster, which paved the way for bitter nationalist diatribes far from the show of unity and solidarity that the European Commission expected. The year 2021 started with the Italian press accusing Germany of diverting doses destined for Italy after Germany decided to buy doses directly from Pfizer/BiotNtech outside the European Commission's contracts. These accusations were partly relayed by the Italian Prime Minister and firmly rejected by the German Health Minister, who nevertheless acknowledged the existence of these new contracts, 
although countries cannot negotiate bilaterally with the vaccine-producers in parallel with the EU's scheme. The EU may end up being blamed if it does not find a quick solution to the scarcity of vaccines.

\section{ASEAN and the Global Politics of Vaccine Diplomacy}

Unlike the EU, ASEAN does not have an operating vaccine testing facility or a group purchasing program. The Reserve Fund can potentially be used for joint procurement of vaccines to negotiate better prices for the whole of ASEAN. However, as we have seen above, the Reserve Fund was put in place in November 2020 only and has not yet the expertise and the necessary funding to purchase billions of doses. The Regional Public Health Laboratories Network (RPHL) led by Thailand could test the vaccines and exchange information. However, there is no ASEAN regulatory body which can approve vaccines for the whole region, and each member state has to approve each vaccine before they can be used, which takes more time and is more costly. This implies that each member state must follow its own policy to get the vaccine.

In general, Asia has managed to control the pandemic scale by taking drastic containment and tracing measures that have not been implemented with the same effectiveness in Western countries (see Table 1). In ASEAN, the fatality rate is 2.3 versus 2.2 at world level. The number of reported cases per 100,000 inhabitants is much lower than in Europe. Indonesia, the largest country of ASEAN, is also the worst-hit country. Brunei, the smallest country, has had no indigenous cases for months, and all the new issues come from travellers returning to Brunei, and going immediately to quarantine. Surprisingly, the poorest countries of ASEAN, Cambodia and Lao PDR, fare better than the average. The most prosperous country, Singapore, has a high share of cases, but mortality equals to zero. Although there is no cause for celebration, the situation is not direr. This explains why, contrary to Europe, most ASEAN countries are not in the urgency to start a vaccination campaign immediately. They have followed different strategies depending on the pandemic state in their own country, their scientific and industrial capacities, and finally their geopolitical relations with the large powers in Asia, particularly China.

China is the country from which the crisis erupted and worked hard to rebrand its image as the country providing the solution. China was the first country to "flatten the curve" on 29 February 2020 and to control the epidemic. There have been only sporadic and limited resurgences of the epidemic since then, to the point that China is almost COVID free. This gave China an early start in the race to develop a vaccine. During the first months, it was 
thought that Chinese pharmaceutical companies (Sinovac, Sinopharm and CanSino Biologics) would be the first to break through (Takada, 2020). Three out of four Chinese most advanced vaccines rely on the tried and tested technologies of inactivated virus vaccines, which does not require refrigeration at very low temperatures, like the Pfizer/BioNtech or Moderna vaccines. They can be transported at normal refrigeration temperatures, making their distribution much easier and cheaper for developing countries. Another advantage is that Chinese companies dispose of huge manufacturing capacities that they can use to export at a huge scale because the epidemic is under control internally (Tan \& Maulia, 2020). This has allowed China to embark on a far-reaching diplomatic strategy, often referred to as "vaccine diplomacy", aimed primarily at developing countries, to gain influence and recognition. In May 2020, in a speech to the General Assembly of the WHO, President Xi Jinping declared that "Covid-19 vaccine development and deployment in China, when available, will be made a global public good, which will be China's contribution to ensuring vaccine accessibility and affordability in developing countries" (Gretler, 2020). He also pledged to provide \$2billion over two years to the WHO to fight against the pandemic. This in marked contrast with the "America first" policy of the Trump administration, which not only withdrew from the WHO but tried to monopolise vaccines for the USA thanks to a policy of exclusive contracts with the most promising pharmaceutical companies, even when they were foreign companies. It was later specified that Chinese vaccines would be sold "at a fair and reasonable price" (Global Times, 2020), which explains that China multiplied bilateral agreements with developing countries to provide loans, including a $\$ 1$ bn pledge to Latin American and Caribbean countries, to support purchases of Chinese vaccines (Shepherd \& Yang, 2020). These loans have been included for some in the framework of the "new silk roads" renamed on this occasion, "Health Silk Roads" (Mardell, 2020a).

In an attempt to be the first country to develop the vaccine, China followed a twopronged policy. Firstly, In July 2020, Chinese companies led by Sinovac, Sinopharm and CanSino Biologics embarked in a high-risk strategy by administering their vaccines to hundreds of thousands of Chinese even though the final stage or the phase 3 trials designed to confirm overall effectiveness had not been completed (Shepherd, 2020). Secondly, due to China's lack of positive cases, Chinese pharmaceutical companies have carried out phase 3 trials with 18 foreign countries (among them, Argentina, Brazil, Bahrein, the United Arab Emirates, Bangladesh, Indonesia, Pakistan). Some of these agreements include pledges to distribute vaccines in the host country or even to produce part of it locally (Shin \& Hadano, 2021) (Mardell, 2020b). In Southeast Asia, Indonesia and the Philippines are the most 
significant countries where these contracts have been signed. After Russia announced that its Sputnik vaccine was ready although it had not cleared third phase trial, Filipino Prime Minister Duterte "even offered himself and his country as laboratory specimens" and placed all his hopes in the Chinese and Russian vaccines and shunned Western vaccines (Heydarian, 2021). This did not seem to convince the Filipinos who are concerned for their safety. Duterte refused to order vaccines for a long time before changing his mind, which explains that the Philippines has trailed regional peers in securing vaccines (Reuters, 2021). Malaysia was offered priority access to Chinese vaccines, which it has accepted while maintaining various vaccines sources, in particular purchases of BioNTech/Pfizer (Nakano, 2021) (Kumar, 2021). Surprisingly, Cambodia, which received the same proposal, declared through its Prime Minister that "Cambodia is not a dustbin... and not a place for a vaccine trial" and would only purchase vaccines certified by the World Health Organization (WHO). This was interpreted as a rebuff of China (Turton, 2020) while it is more a message that seeks to reassure the Cambodian population and to encourage China to obtain WHO certification for its vaccines (Strangio, 2021). In Indonesia, "Sinovac will dispatch 3 million finished doses of coronavirus vaccine and enough vaccine bulk -- the liquid eventually divided into vials -- for Bio Farma to locally manufacture 15 million doses by the end of December. Sinovac also has agreed to supply 125 million doses next year" (Tan \& Maulia, 2020).

Several commentators believe that the Chinese vaccines come with strings attached such as support from Southeast Asian countries to China in its conflict with the USA and a compromise regarding Chinese territorial claims in the South China sea (Strangio, 2020b). This political price explains that most Southeast Asian countries have tried to avoid an overdependence on China to get vaccines. Another strong motive is that Chinese pharmaceutical companies deviated from international standards for transparency during drug development. The underlying data and the details of analysis carried out by Sinopharm or the Chinese regulatory bodies were not released. This has cast doubt on their safety, especially since the first results concerning their effectiveness (around 70 percent) were disappointing compared to the vaccines from Pfizer /BioNtech and Moderna (around 90 percent) which have been approved by recognised regulatory bodies in the United States, Europe, and even at WHO (Shin \& Takada, 2020). This indicates why many ASEAN member states are trying to diversify their sources of vaccines. Table 2 shows that all ASEAN member states have signed up with COVAX. Brunei, Malaysia and Singapore as self-financing countries and the rest as middleincome countries eligible as to be supported by the COVAX Advanced Market Commitment (AMC). The COVAX scheme will provide ASEAN with a possibility to vaccine up to 20 
percent of its population in the second part of 2021 when the vaccines will be approved and available. In the meantime, the richest member states are purchasing Pfizer/BioNtech and Moderna vaccines, which are expensive and difficult to get because high-income countries have placed earlier very large orders. The Minister of Health of Malaysia states that "no company can provide 100 percent supply to Malaysia because developed countries bought (the vaccines) earlier than us as they can offer more and they can make decisions because their budgets are much bigger than ours" (Bernama, 2020). This is one reason why several member states have signed contracts with Chinese companies despite their absence of approval by stringent regulatory bodies. Some have even signed with the Russian company Gamaleya, that is the less transparent in terms of data test sharing. Regarding Western companies, the most successful in the near future will probably be Oxford/AstraZeneca, which has agreed to manufacture its vaccines in Thailand in a joint venture with a Thai company, Siam Bioscience. The advantage of this vaccine is that it is cheaper and can "hold on to its potency for at least six months in a standard refrigerator. That compares with about one month for Moderna's offering and only a few days for Pfizer's" (Zsombor, 2020). Chinese and Russian vaccines can also be stored at usual temperatures. Thailand expects to become a hub and exports to the rest of ASEAN. They may benefit from India's decision to temporarily ban the "Serum Institute of India", which has been contracted to make 1 billion doses of the Oxford/AstraZeneca vaccine for developing nations, most of which are delivered to COVAX. Other A member state like Singapore and Vietnam have partnered with foreign laboratories to develop their own vaccines. These efforts to develop local capacities are important for the future because it shows that ASEAN could become less dependent on big powers to vaccinate a large share of its population. ASEAN could potentially play a role in organising and planning ASEAN selfsufficiency.

\section{Conclusion}

Comparing the EU and ASEAN's response to the COVID-19 pandemic is useful to highlight regions' role. In this regard, as Beeson and Murray (2020), the EU is not a model to be followed by ASEAN, but a "reference point". Because the EU has opted for a far higher level of political and economic integration and dispose of considerable institutional and financial power, Europeans expected it to bring an effective response to mitigate the impact of the crisis. It appears that both regions were ill-prepared to deal with this crisis even though they had mechanisms in place created during previous epidemics. They seriously underestimated the 
gravity of the coming's epidemic, although some renowned experts gave an early warning. In both cases, the region was unable to organise a joint response in emergency times and prevent national preference from overring with regional interest. The unilateral and disorderly closure of borders and the ban on PPE export is a testament to this. Discredit was significant for the EU at a time in its history when it was already weakened by decades of neo-liberal policies reducing the state's capacity to intervene, the rise of populism, and Brexit. The Europeans have experienced that the EU is not providing them with the protection they need at the worst time of the crisis. In ASEAN, there was no such expectation, so in a sense, there was no disillusion. Still, ASEAN could have played a better job in raising awareness among the region's governments about the seriousness of the shock that was about to come and what were the urgent decisions to take to be better prepared. This would have prevented the loss of precious time by some governments at the start in a state of denial. Even without the support of a strong organisation, ASEAN could have better played this early warning role.

After the shock of the first wave, the two regions attempted to play a more significant role. The EU put all its weight in economic rescue policies, with colossal spending schemes, which were adopted with difficulties due to some of its members' behaviour. It remains to be seen how the money will be spent, particularly if the vast investments planned will help the European Union accelerate the energy transition and create hundreds of thousands of new "green jobs" or if the "business as usual" will prevail. ASEAN has no regional budget as such, and all it can do is discuss the appropriate economic policy. Since the so-called Asian crisis of 1997-98, and the Chiang Mai Initiative that followed in 2000, it has put in place the ASEAN+3 group which can advise, monitor, and if possible, coordinate the economic policies implemented by ASEAN member states. However, it is purely indicative, and there are no binding agreements.

In the end, it is the health issue that will decide the relevance of the respective regions. In this regard, the EU has also lost an opportunity. The EU could have channelled the considerable amount of money it has used to finance private pharmaceutical companies to fund a network of European public laboratories instead to develop rapidly licence-free vaccines that could have been genuine public goods. In October 2020, South Africa and India supported by 99 countries, made the same kind of proposal at a World Trade Organisation meeting. The proposal "allowed countries to ignore patents relating to Covid-19 drugs and vaccines until global immunity is achieved" (Cieśla \& Eliassen, 2020). The EU and other high-income countries did not support it. Instead, the choice was made to finance "national champions" which later refused to make public the detailed test results funded by public money. Public 
universities and laboratories could have checked them rapidly, avoiding the loss of a precious time. The EU could have decided to put all its weight and might in support of COVAX and order vaccines only through this mechanism. Instead, the EU joined the scramble to vaccines, contributing with other large powers to the global shortage, which delays vaccines deliveries through the COVAX scheme. Some Southeast Asian countries are in the same situation. They expect to develop their own vaccines or manufacture vaccines developed elsewhere to take a share of the future global market. The pandemic may last several years, and people may have to be vaccinated regularly, such it is the case for the common flu. This shows that to understand what regions can or cannot do, a political economy analysis of each member state is essential to gauge the extent to which they have an economic interest or not in supporting a regional or a solely national response to a crisis.

\section{References}

Abboud, L., \& Peel, M. (2020, 07-29). Covid-19 hastens French push to bring home medicines manufacture. Financial Times. https://www.ft.com/content/80a4836b-ca25-48e0-996d$\underline{458186 \mathrm{e} 968 \mathrm{dc}}$

Adlakha, H. (2020, 10-23). Did China Join COVAX to Counter or Promote Vaccine Nationalism? The Diplomat. https://thediplomat.com/2020/10/did-china-join-covax-tocounter-or-promote-vaccine-nationalism/

ASEAN. (2020, 02-04). ASEAN Plus Three senior health officials reaffirm cooperation to stop spread of COVID-19. Retrieved 30/12/2020 from https://asean.org/asean-plus-three-seniorhealth-officials-reaffirm-cooperation-stop-spread-2019-ncov/

Beeson, M. (2020). A plague on both your houses: European and Asian responses to Coronavirus. Asia Europe Journal, 18, 245-249.

Beeson, M., \& Murray, P. (2020). Testing Times for Regionalism: Coping with Great Power Rivalry in the Asia-Pacific. Asian Studies Review, 44(1), 1-9. https://doi.org/10.1080/10357823.2020.1681052

Bernama. (2020, 12-24). Covid-19 vaccine: Second purchase from AstraZeneca via COVAX. The Edge Markets. Retrieved 10/01/2021 from http://www.theedgemarkets.com/article/covid19-vaccine-second-purchase-astrazeneca$\underline{\text { covax---khairy }}$ 
Brundsen, J., \& Flemming, S. (2020, 05-27). Von der Leyen seeks to rally Europe behind 'next generation' recovery plan. Financial Times. https://www.ft.com/content/ea010e87-4b8a-40ff9a0c-0610d8fa3d02

Chazan, G., Neville, S., \& Abboud, L. (2021, 01-01). European leaders under pressure to speed up mass vaccination. Financial Times. https://www.ft.com/content/c45e5d1c-a9ea-4838-824c$\underline{413236190 \mathrm{e} 7 \mathrm{e}}$

Cieśla, W., \& Eliassen, I. (2020, 11-25). History repeats itself: Attempts to prevent vaccine injustice have provided questionable results. @investigate_eu. https://www.investigateeurope.eu/fr/2020/covid-vaccine-distribution-cepi-covax/

CSIS. (2020). Southeast Asia Covid-19 Tracker. Retrieved 30/12/2020 from https://www.csis.org/programs/southeast-asia-program/southeast-asia-covid-19-tracker-0

Dalpino, C. (2020). US-Southeast Asia Relations: Diplomatic Doldrums: ASEAN Loses Momentum in The Pandemic as Security Tensions Rise. Comparative Connections, 22(2), 5160.

Dennison, S., \& Zerka, P. (2020). Together in trauma: Europeans and the world after covid19 (Policy Brief, Issue. ECFR.)

https://ecfr.eu/publication/together_in_trauma_europeans_and_the_world_after_covid_19/ Ducanes, G., Dutta, P., \& Nixon, N. (2020). Displaced, Stranded, Unprotected: ASEAN's Migrant Workers. The Diplomat. https://thediplomat.com/2020/12/displaced-strandedunprotected-aseans-migrant-workers/

Enderwick, P., \& Buckley, P. J. (2020). Rising regionalization: will the post-COVID-19 world see a retreat from globalization? Transnational Corporations Journal, 27(2).

European Commission. (2020a). Crisis management and solidarity. https://ec.europa.eu/info/live-work-travel-eu/coronavirus-response/crisis-management-andsolidarity_en

European Commission. (2020b). Public health. Retrieved 23/12/20 from https://ec.europa.eu/info/policies/public-health_en

European Commission. (2020c). Building a European Health Union: Reinforcing the EU's resilience for crossborder health threats. Brussels. COM(2020) 724 final.

European Commission. (2020d). EU increases contribution to COVAX to $€ 500$ million.

European Commission. Retrieved 05/01/2021 from

https://ec.europa.eu/commission/presscorner/detail/en/ip_20_2075 
European Commission. (2020e). Coronavirus: Commission approves contract with Moderna. European Commission. Retrieved 03/01/2021 from

https://ec.europa.eu/commission/presscorner/detail/en/ip_20_2200

European Parliament. (2020). Public opinion survey EU COVID19-Third Survey. European

Parliament. Retrieved 27/12/2020 from

https://www.google.com/search?client=safari\&rls=en\&q=Public+opinion+survey+EU+COV

$\underline{\text { ID19\&ie }=\mathrm{UTF}-8 \& \text { oe }=\mathrm{UTF}-8}$

GAVI. (2021). Gavi, the Vaccine Alliance. Retrieved 05/01/2021 from https://www.gavi.org/

Giles, C. (2020, 11-22). G20 leaders pledge to ensure global access to Covid vaccines.

Financial Times. https://www.ft.com/content/5f5e5a8c-1b94-438f-8f10-212126883e6c

Gretler, C. (2020, 05-18). Xi Vows China Will Share Vaccine and Gives WHO Full Backing.

Bloomberg. Retrieved 08/01/2021 from https://www.bloomberg.com/news/articles/2020-05-

$\underline{\text { 18/china-s-virus-vaccine-will-be-global-public-good-xi-says }}$

Guarascio, F. (2020, 12-14). EU weighs donating 5\% of its COVID-19 vaccines to poor nations- document. @ @euters. Retrieved 05/01/2021 from https://www.reuters.com/article/health-coronavirus-eu-who-idUSL8N2IR4J4

Guarascio, F., \& Blenkinsop, P. (2020, 03-06). EU fails to persuade France, Germany to lift coronavirus health gear controls. Reuters. https://www.reuters.com/article/us-healthcoronavirus-eu-idUSKBN20T166

Hailey, R. (2020). The state of supply chains: Pharma and the vaccine race part one Reuters. Retrieved 03/01/2021 from https://www.reutersevents.com/supplychain/supply-chain/statesupply-chains-pharma-and-vaccine-race-part-one

Herszenhorn, D. M., \& Wheaton, S. (2020, 04-07). How Europe failed the coronavirus test. Politico. https://www.politico.eu/article/coronavirus-europe-failed-the-test/

Heydarian, R. (2021, 01-21). Duterte's COVID blunders will set the Philippines back generations. Nikkei Asia. https://asia.nikkei.com/Opinion/Duterte-s-COVID-blunders-will-setthe-Philippines-back-generations

Iwamoto, K. (2020, 08-07). COVID confinement stirs fears for Singapore migrants' mental health. Nikkei Asia. https://asia.nikkei.com/Spotlight/Coronavirus/COVID-confinement-stirsfears-for-Singapore-migrants-mental-health

Jack, A. (2020, 10-07). Fighting vaccine nationalism. Financial Times. https://www.ft.com/content/adcf70b1-8d06-4234-95c2-dd23b0a2f605 
Jetin, B. (2018). Production Networks of the Asian Automobile Industry: Regional or Global? International Journal of Automobile Technology and Management, 18(4), 302-328. https://doi.org/10.1504/IJATM.2018.097346

Kahn, S., \& Prin, E. (2021). In the time of COVID-19, China's mask has fallen with regard to Europe (European Issue, Issue 569). https://www.robert-schuman.eu/en/europeanissues/0569-in-the-time-of-covid-19-china-s-mask-has-fallen-with-regard-to-europe

Khan, M. (2020, 10-02). EU's free traders push back against strategic autonomy mantra. Financial Times. https://www.ft.com/content/0f4fae24-43d3-41fd-b614-04544e97c7c3

Kimura, F., Thangavelu, S. M., Narjoko, D., \& Findlay, C. (2020). Pandemic (COVID-19) Policy, Regional Cooperation and the Emerging Global Production Network. Asian Economic Journal, 34(1), 3-27.

Kumar, P. (2021, 01-11). Malaysia doubles Pfizer COVID vaccine order as it locks down anew. Nikkei Asia. https://asia.nikkei.com/Spotlight/Coronavirus/Malaysia-doubles-Pfizer-COVIDvaccine-order-as-it-locks-down-anew

Mardell, J. (2020a, 11-25). China's "Health Silk Road": Adapting the BRI to a pandemic-era world. MERICS, Mercator Institute for China Studies. Retrieved 08/01/2021 from https://merics.org/en/short-analysis/chinas-health-silk-road-adapting-bri-pandemic-era-world Mardell, J. (2020b, 11-24). China's vaccine diplomacy assumes geopolitical importance. MERICS, Mercator Institute for China Studies. Retrieved 08/01/2021 from https://merics.org/en/short-analysis/chinas-vaccine-diplomacy-assumes-geopoliticalimportance

Maulia, E., \& Damayanti, I. (2020, 12-22). Pandemic stalls Indonesia's push to escape middleincome trap. Nikkei Asia. https://www.ft.com/content/fa65ee18-5fe3-4a43-8b369b7c07757e34

Menon, J. (2020). COVID-19 in East Asia: Impacts and Response. Thailand and The World Economy, 38(2), 119-127.

Michel, C. (2020, 09-08). Recovery Plan: powering Europe's strategic autonomy. European Council. https://www.consilium.europa.eu/en/press/press-releases/2020/09/08/recovery-planpowering-europe-s-strategic-autonomy-speech-by-president-charles-michel-at-the-brusselseconomic-forum/

Nakano, T. (2021, 10-14). Malaysia promised priority access to China's COVID vaccine. Nikkei Asia. https://asia.nikkei.com/Politics/International-relations/Malaysia-promisedpriority-access-to-China-s-COVID-vaccine 
Papageorgiou, M., \& Melo, D. S. N. (2020). Regional responses to COVID-19: A comparative analysis of EU and ASEAN policies to counter the pandemic amid Challenging Times. Perspectives on Federalism, 10(2), 68.

Peel, M., Khan, M., \& Fleming, S. (2020, 12-11). EU countries agree historic $€ 1.8$ tn budget and recovery package. Financial Times. https://www.ft.com/content/03d72613-1745-45209ba3-5a94c8a3963f

Politi, J. (2020, 02-12). US trade adviser seeks to replace Chinese drug supplies. Financial Times. https://www.ft.com/content/73751cca-4d1a-11ea-95a0-43d18ec715f5

Pooler, M., \& Hale, T. (2020, 09-17). Coronavirus and globalisation: the surprising resilience of container shipping. Financial Times. https://www.ft.com/content/65fe4650-5d90-41bc$\underline{8025-4 a c 81 \mathrm{df} 8 \mathrm{a} 5 \mathrm{e} 4}$

Reuters. (2021, 01-14). Philippines approves Pfizer-BioNTech vaccine for emergency use. Nikkei Asia. https://asia.nikkei.com/Spotlight/Coronavirus/Philippines-approves-PfizerBioNTech-vaccine-for-emergency-use

Saha, P. (2020). Decoding the initial response and ongoing impact of COViD-19 in Southeast Asia. In K. Bommakanti (Ed.), China's Strategic Ambitions in the Age of COVID-19 (pp. 62). Observer Research Foundation.

Schulz, T., Schult, C., Knobbe, M., Hackenbroch, V., \& Becker, M. (2020, 12-18). Corona: Germany and Europe Could Fall Short on Vaccine Supplies. Der Spiegel International. https://www.spiegel.de/international/europe/the-planning-disaster-germany-and-europecould-fall-short-on-vaccine-supplies-a-3db4702d-ae23-4e85-85b7-20145a898abd

Sevastopulo, D., \& Williams, A. (2020, 08-06). Donald Trump to order government to buy medicines from US companies. Financial Times. https://www.ft.com/content/14b71ce4-0f574e9f-a2a6-5380229cf8c5

Shepherd, C., \& Yang, Y. (2020, 12-20). Anxiety clouds China's rush to vaccinate parts of the world. Financial Times. https://www.ft.com/content/d8d9a691-831f-4942-a8f2-9b6f80f43b0b Shin, W., \& Hadano, T. (2021, 09-18). China expands testing to 18 nations in vaccine charm offensive. Nikkei Asia. https://asia.nikkei.com/Spotlight/Coronavirus/China-expands-testingto-18-nations-in-vaccine-charm-offensive

Shin, W., \& Takada, N. (2020). China slips in COVID-19 vaccine race on doubts over effectiveness. Nikkei Asia. https://asia.nikkei.com/Spotlight/Coronavirus/China-slips-inCOVID-19-vaccine-race-on-doubts-over-effectiveness

Stacey, K. (2020, 2020-12-31). Trump administration admits missing Covid vaccination goals. Financial Times. https://www.ft.com/content/375337b2-7a3f-4010-8f0f-b0ed32c0149d 
Stiglitz, J. E. (2020, 04-15). We need a balance between Globalisation and Self-Reliance. Foreign Policy. https://foreignpolicy.com/2020/04/15/

Strangio, S. (2020a, 06/12). COVID-19 Recovery Dominates Weekend of Asian Summits. The Diplomat. https://thediplomat.com/2020/11/covid-19-recovery-dominates-weekend-of-asiansummits/

Strangio, S. (2020b, 05/11/2020). China's Southeast Asian 'Vaccine Diplomacy’ comes into relief. The Diplomat. https://thediplomat.com/2020/11/chinas-southeast-asian-vaccinediplomacy-comes-into-relief/

Strangio, S. (2021, 12-22). Is Cambodia Really Turning Its Back on Chinese Vaccines? The Diplomat. https://thediplomat.com/2020/12/is-cambodia-really-turning-its-back-on-chinesevaccines/

Takada, N. (2020, 08-17). China's lead in coronavirus vaccines raises concern as well as hope. Nikkei Asia. https://asia.nikkei.com/Spotlight/Coronavirus/China-s-lead-in-coronavirusvaccines-raises-concern-as-well-as-hope

Tan, C., \& Maulia, E. (2020, 11-04). Red Pill? Behind China's COVID-19 vaccine diplomacy. Nikkei Asia. https://asia.nikkei.com/Spotlight/The-Big-Story/Red-Pill-Behind-China-sCOVID-19-vaccine-diplomacy

Times, G. (2020, 09-30). China to provide COVID-19 vaccines to the world at reasonable price: spokesperson. Global Times. https://www.globaltimes.cn/content/1202538.shtml

Turton, S. (2020). Cambodia shuns China's Sinovac vaccine in favor of COVAX shots. Nikkei Asia. $\quad$ https://asia.nikkei.com/Spotlight/Coronavirus/Cambodia-shuns-China-s-Sinovacvaccine-in-favor-of-COVAX-shots

Twohey, M., Collins, K., \& Thomas, K. (2020, 12-15). With First Dibs on Vaccines, Rich Countries Have 'Cleared the Shelves'. The New York Times. https://www.nytimes.com/2020/12/15/us/coronavirus-vaccine-doses-reserved.html

Viet, A. (2020). Vietnam commits $\$ 5$ million to ASEAN Covid-19 response fund - VnExpress International. VNExpress International. https://e.vnexpress.net/news/news/vietnam-commits5-million-to-asean-covid-19-response-fund-4190837.html

Virgil, D., \& Lie, R. (2020). ASEAN's Covid-19 Response: Why Minorities and the Most Vulnerable Matter. Global Asia, 15(2), 110-115.

Zsombor, P. (2020). Thai Firm Joins with AstraZeneca to Make COVID-19 Vaccine for Southeast Asia. @VOANews. Retrieved 01-10 from https://www.voanews.com/covid-19pandemic/thai-firm-joins-astrazeneca-make-covid-19-vaccine-southeast-asia 
Table 1: COVID-19 Incidence in ASEAN and selected countries, as of 04/01/2021.

\begin{tabular}{|c|c|c|c|c|}
\hline Country & $\begin{array}{c}\text { Total } \\
\text { confirmed } \\
\text { cases }\end{array}$ & Total deaths & $\begin{array}{c}\text { Case fatality } \\
\text { rate }\end{array}$ & $\begin{array}{c}\text { Reported } \\
\text { cases per } \\
100,000\end{array}$ \\
\hline Brunei & 172 & 3 & 1,7 & 39 \\
\hline Cambodia & 381 & & & 2 \\
\hline Indonesia & 763350 & 22734 & 3,0 & 293 \\
\hline Lao PDR & 41 & & & 1 \\
\hline Malaysia & 119077 & 494 & 0,4 & 365 \\
\hline Myanmar & 126345 & 2728 & 2,2 & 239 \\
\hline Philippines & 477807 & 9257 & 1,9 & 462 \\
\hline Singapore & 58697 & 29 & 0,0 & 1516 \\
\hline Thailand & 7694 & 64 & 0,8 & 11 \\
\hline Vietnam & 1494 & 35 & 2,3 & 2 \\
\hline Japan & 240954 & 3548 & 1,5 & 190 \\
\hline South Korea & 63244 & 962 & 1,5 & 122 \\
\hline Australia & 28483 & 909 & 3,2 & 111 \\
\hline New Zealand & 2181 & 25 & 1,1 & 45 \\
\hline India & 10339728 & 149659 & 1,4 & 854 \\
\hline USA & 21015374 & 359673 & 1,7 & 6402 \\
\hline Belgium & 649169 & 19644 & 3,0 & 5683 \\
\hline France & 2643239 & 65037 & 2,5 & 3946 \\
\hline Germany & 1783571 & 35225 & 2,0 & 2145 \\
\hline Italy & 2155446 & 75332 & 3,5 & 3567 \\
\hline Spain & 1928265 & 50837 & 2,6 & 4100 \\
\hline UK & 2654779 & 75024 & 2,8 & 3993 \\
\hline
\end{tabular}

Source: Computed by the author with Data from ASEAN Biodiaspora Virtual Center (ABVC), accessed on 06/01/2021. 
Table 2: Vaccines procurement from Asian countries

\begin{tabular}{|c|c|c|c|c|c|c|c|c|c|c|c|c|}
\hline Country & COVAX & Sinovac & Sinopharm & $\begin{array}{c}\text { Cansino } \\
\text { Biologics }\end{array}$ & $\begin{array}{c}\text { Pfizer/ } \\
\text { BioNtech }\end{array}$ & Moderna & $\begin{array}{c}\text { Oxford - } \\
\text { AstraZeneca }\end{array}$ & $\begin{array}{c}\text { Johnson } \\
\& \\
\text { Johnson }\end{array}$ & Novavax & $\begin{array}{c}\text { Gamaleya } \\
\text { Sputnik }\end{array}$ & Medigen & Local \\
\hline Brunei & $X$ & & & & & & & & & & & \\
\hline Cambodia & $\mathrm{X}$ & $\mathrm{X}$ & $\mathrm{X}$ & & & & & & & $\mathrm{X}$ & & \\
\hline Indonesia & X & $X$ & $X$ & & $\mathrm{X}$ & & $X$ & & $\mathrm{X}$ & & & \\
\hline Lao PDR & $X$ & $\mathrm{X}$ & $X$ & & & & & & & $\mathrm{X}$ & & \\
\hline Malaysia & $\mathrm{X}$ & $\mathrm{X}$ & & $\mathrm{X}$ & $\mathrm{X}$ & & $\mathrm{X}$ & & & $\mathrm{X}$ & & \\
\hline Myanmar & $\mathrm{X}$ & & & & & & & & & & & \\
\hline Philippines & $\mathrm{X}$ & $\mathrm{X}$ & & & & $\mathrm{X}$ & $X$ & & $\mathrm{X}$ & $\mathrm{X}$ & & \\
\hline Singapore & $\mathrm{X}$ & $\mathrm{X}$ & & & $\mathrm{X}$ & $\mathrm{X}$ & & & & & & $\mathrm{X}$ \\
\hline Thailand & $\mathrm{X}$ & $X$ & & & & & $\mathrm{X}$ & & & & & $\mathrm{X}$ \\
\hline Vietnam & $\mathrm{X}$ & $\mathrm{X}$ & & & $\mathrm{X}$ & & $\mathrm{X}$ & & & $\mathrm{X}$ & $\mathrm{X}$ & $\mathrm{X}$ \\
\hline India & $\mathrm{X}$ & & & & & & $\mathrm{X}$ & $\mathrm{X}$ & $\mathrm{X}$ & $\mathrm{X}$ & & $\mathrm{X}$ \\
\hline Japan & $\mathrm{X}$ & & & & $\mathrm{X}$ & $\mathrm{X}$ & $\mathrm{X}$ & & $\mathrm{X}$ & & & \\
\hline $\begin{array}{l}\text { South } \\
\text { Korea }\end{array}$ & $\mathrm{X}$ & & & & $\mathrm{X}$ & $\mathrm{X}$ & $\mathrm{X}$ & $\mathrm{X}$ & & & & $\mathrm{X}$ \\
\hline Taiwan & & & & & $\mathrm{X}$ & & & & & & & \\
\hline
\end{tabular}

Source: Author's elaboration based on Newspapers and online media accessed on 09/01/2021. 